\title{
INVESTAVIMAS I ATEITIES SANDORIUS NAUDOJANT MONTE CARLO IR SHARPO METODUS
}

\author{
Ieva ŽOLNEROVIČIŪTÉ*, Nijolè MAKNICKIENĖ \\ Vilniaus Gedimino technikos universitetas, Verslo vadybos fakultetas, \\ Finansu inžinerijos katedra, Sauletekio al. 11, LT-10223, Vilnius, Lietuva \\ "El.paštas ieva.zolneroviciute@stud.vgtu.lt
}

\begin{abstract}
Santrauka. Pasaulinė išvestinių finansinių priemonių rinka yra dinamiškai augantis finansų rinkos segmentas. Nauji finansiniai produktai daro ekonominius santykius sudètingesniais ir atsiranda naujų finansinių naujovių poreikis. Atsiranda pasaulinė tinklo ekonomika, kuri remiasi elektroninemis jos veikimo sistemomis, per kelias sekundes perkelia milijardus dolerių i kitas rinkas. Ateities sandorių augimo dinamika pasaulyje per pastaruosius metus rodo, kad ši finansų rinkos dalis sparčiai vystosi. Maži transakcijų kaštai bei lengvas šių priemonių panaudojimas suteikia investuotojams daug galimybių kryptingai planuoti pinigų srautus bei siekti norimos grąžos. Dèl šios priežasties labai svarbu išanalizuoti ir tinkamai ịvertinti ateities išvestinių sandorių galimas kainų kitimo kryptis ir tendencijas. Tam darbe sujungti du algoritmai, kaip paramos sistema investuotojui: prognozuojantis Monte Carlo metodas, kuris rodo atskirų instrumentų kitimo tendencijas, leidžia ịžvelgti pirkimo ir pardavimo signalus, rinkos aktyvumą ir pasyvumą bei pasirinkti įejjimo ị rinką laiką, kad prekyba būtu pelninga; kitas - optimizuojantis, leidžiantis sudaryti efektyvų portfelį, Sharpo metodas. Pasitelkiant šiais algoritminiais metodais bei jų rezultatais prognozuojamos ateities sandoriu kainos ir sudaromas investicinis portfelis su tikètina grąža ir mažesne rizika.
\end{abstract}

Reikšminiai žodžiai: išvestinès finansinès priemonès, ateities sandoris, rinka, algoritminè prekyba, Monte Carlo metodas, Sharpo metodas, tendencijos.

\section{İvadas}

Ekonominè globalizacija ir integracija pasaulio finansų rinkoje pakeitè jos struktūrą ir sukūrè naujus vystymosi segmentus. XX a. pabaigoje tokių naujovių rezultatas buvo išvestinių finansinių priemonių rinkos atsiradimas, kuris rinkai suteikė naujas, anksčiau nepasiekiamas, finansinès rizikos valdymo galimybes. Investuotojai turi gana platų finansinių priemonių ir galimybių spektrą, kurio pagalba galima uždirbti pinigus iš akcijų ir vertybinių popierių. Išvestinių finansinių priemonių rinka yra vienas pagrindinių ir aktyviausių šiuolaikinės finansų sistemos segmentụ. Tačiau dauguma naujokų investuotojų labai mažai žino, kokios yra išvestinès finansinės priemonès, jų teikiama nauda. Atitinkamai tokios priemonès, kurios suteikia investuotojui daug galimybių, lieka nepanaudotos. Arba priešingai, investuotojai neapgalvotai rizikuoja, nesuprasdami šių priemoniu rizikos. Nutarus investuoti, būtina atsižvelgti ị riziką, pelningumą ir padètị pasaulio vertybinių popierių rinkoje. Investicijos yra įmonių ir privačiu asmenų ekonominè veikla. Tvirta investicija išsprendžia visą ekonominių užduočiu kompleksą mikro, makro ir mezo lygmeniu, sukuria palankias sąlygas ekonomikai vystytis (Lutsenko et al., 2017). Atsižvelgiant ị tarptautiniu santykių komplikacijas, ekonomikos sukrètimus, staigius kainų pokyčius finansų rinkoje, įmonės privalo įdiegti veiksmingus metodus, kaip sumažinti riziką, kuri galètų tinkamai reaguoti ị šiuolaikinius ekonominius iššūkius.

Pasaulyje sparčiai plintant inovacijoms greitai ị rinką veržiasi naujas prekybos segmentas, pagrịstas prekybos automatizavimu, tai - algoritminè prekyba. Dẻl to galima teigti, kad itin trumpalaikés automatinès prekybos segmentas turi geras tolesnio vystymosi perspektyvas, o algoritminių sistemų pranašumai leidžia mums juos laikyti kitu technologinių inovacijų finansų rinkose etapu. Vienas iš algoritminès prekybos plètros rezultatụ yra tas, kad robotai pamažu išstumia paprastus prekybininkus iš prekybos ir tikimasi, kad ši tendencija tik sustiprès. Prekybos automatizavimas leidžia tinkamai išnaudoti rinkos tendencijas. Algoritmine prekyba leidžia neutralizuoti daugeli trūkumų esančių finansinių instrumentų prekyboje. Tai paskatino per trumpą laiką algoritmines sistemas išplisti ir augti pasaulineje rinkoje. Algoritminès prekybos modeliai naudojami siekiant padalinti didelius pavedimus ị kelias mažesnes operacijas bei suvaldyti riziką ir ịtaką rizikai. Svarbu ịvertinti algoritminės prekybos modeliụ perspektyvas ir įtaką finansinių instrumentų rinkos pletrai. Visame pasaulyje finansinès organizacijos aktyviai reorganizuoja savo veiklą robotizuodamos sistemas prekyboje, todèl ši sistema yra labai aktuali. 
Tyrimo problema - kaip sujungti Monte Carlo ir Sharpo metodus ị bendrą algoritminès prekybos modelị.

Tyrimo objektas - ateities sandoriai.

Tyrimo tikslas - atlikus ateities sandorių ir algoritminių modelių literatūros analizę, pritaikyti Monte Carlo ir Sharpo algoritmus investavimui $i$ ateities sandorius.

Tyrimo uždaviniai:

- Išanalizavus mokslinę literatūrą atskleisti ateities sandorių savybes ir ịvertinti rinkos tendencijas.

- Apžvelgti algoritminès prekybos modelius.

- Prognozuoti naftos, aukso ir gamtinių dujų ateities sandorių kainas Monte Carlo metodu.

- Gautų prognozių pagrindu sudaryti naftos, aukso ir gamtinių dujų ateities sandorių investicini portfelị naudojant Sharpo modeli.

\section{Ateities sandorių rinkos teoriniai aspektai}

Pasaulinė išvestinių finansinių priemonių rinka yra dinamiškai augantis finansų rinkos segmentas. Dẻl didelių pinigų valdymo galimybių su minimaliomis išlaidomis, išvestinių finansinių priemonių rinka padeda efektyviai spręsti kainų svyravimo problemą, optimizuodama įmonès veiklos pinigų srautus, leidžia pasiekti reikiamą nuosavų ir pasiskolintų léšų santykị, kartu mažinant jų išlaidas, priimti spendimus dẻl investicijų, kurie geriausiai atitiktų imonių poreikius ir politiką (Saakian, 2018). Išvestinès finansinès priemonès yra nauji finansiniai produktai, kurie susidarè dẻl specifinių ekonominių subjektų santykių finansų rinkoje. Šie santykiai leidžia patenkinti poreikius, susijusius su finansavimo šaltinių paieška, siūlo dideles galimybes keisti rizikos dydį, perskirstant ją ir užtikrinti likvidumą bei pagerinti galutinius finansinius rezultatus. Nuolat besikeičiant valiutų kursams, pasiūlos ir paklausos svyravimams, didejja rizika ir realiam ekonominiam sektoriui tenkanti našta (Abdullah, 2018). Išvestinių finansinių priemonių rinka gali greitai prisitaikyti prie išorinės aplinkos pokyčių ir reikalavimų, naujomis sandorių formomis apsaugoti verslą nuo rizikų. Pastaraisiais metais pasaulio rinkose atsirado tendencija didinti išvestinių finansinių priemonių populiarumą. Pagrindinès išvestinių finansinių priemonių savybės yra skubumas ir sąnaudomis pagrịstas našumas. Verta paminèti, kad egzistuoja biržinès ir nebiržinès išvestinès finansinès priemonès. Nebiržiniai sandoriai sudaromi tiesiogiai tarp pardavejo ir išvestinès finansinès priemonès pirkèjo. Jie pagrįsti pirkèjo reikalavimais ir norais. Ir skirtingai nei šioms sutartims, biržos rinkoje taikomos griežtos standartizuotos išvestinès finansinès priemonės. Paprastai išvestinės finansinès priemonės nenaudojamos fiziniam pagrindinio turto ịsigijimui, bet reikalingos siekiant apriboti galimus nuostolius, atsirandančius dèl kainų svyravimų arba išgauti spekuliacinị pelną. Vienas iš pagrindinių išvestinių finansinių priemonių naudojimo tikslų yra rizikos mažinimas. Vo et al. (2019) pabrèžia, kad norint veiksmingai naudoti išvestines finansines priemones, reikalingas gerai suderintas išvestinių finansinių priemonių rinkos veikimo mechanizmas, taip pat svarbiausių ryšių su jais ịstaigų plètra, mainai, kuriais prekiaujama išvestinėmis finansinėmis priemonėmis. Išvestinių finansinių priemonių trukmè yra ribota nuo kelių dienų iki kelių mėnesių. Jų vertè priklauso nuo sandorio turimo turto. Išvestinių finansinių priemonių nustatymas atskleidžia fiktyvios vertès, kaip išvestinès vertès pobūdị. Šios priemonès apima ateities sandorius, sudarytus siekiant gauti spekuliacini pelną arba apdrausti riziką, pagrịstą rinkos turtu, suvienodinant pinigų srautus laike ir erdvejje.

Ateities sandoris - tai susitarimas, kuris yra sudarytas biržoje, pagal kurị sandoris turètų vykti tam tikru momentu pagal rinkos kainą sutarties sudarymo dieną. Birža organizuoja ateities sandorius antrinejje rinkoje ir užtikrina jų vykdymą (Karali et al., 2018). Sandoriai užregistruojami kliringo namuose. Kadangi ateities sandoriai yra standartiniai ir atsiskaitymas yra garantuotas, tai yra labai likvidūs. Tai reiškia, kad prekiautojas gali lengvai uždaryti atvirą poziciją ir kompensuoti sandorị. Jo veiklos rezultatas bus pelnas arba nuostoliai, priklausomai nuo to, kokia kaina buvo atidaryta ir uždaryta pozicija. Jei išankstinio sandorio kaina yra fiksuota, tai ateities sandorių atveju ji gali skirtis priklausomai nuo rinkos sąlygų. Privalomas ateities sandorių reikalavimas, kad prekès bus parduodamos ar perkamos konkrečiu momentu. Abdullah (2018) išskiria ateities sandorio sutarties savybes:

- Turtas (žaliavos, užsienio valiuta, akcijos ir kt.);

- Turto suma;

- Ateities sandorio vykdymo data (galiojimo laikotarpis);

- Fiksuota suma - pirkejjo sumokèta ir pardavejo gauta fiksuota suma.

Suèjus mokẻjimo terminui pirkèjas turi nusipirkti, o pardavèjas turi parduoti turtą pagal sutartą kainą. Mishin (2018) ateities sandorius skirsto ị du tipus:

1. Atsiskaitymas. Tarp sutarties šalių yra atsiskaitymas grynaisiais pinigais. Skaičiavimo suma yra skirtumas tarp nurodytos kainos ir dabartinès turto kainos;

2. Turto pristatymas.

Finansinis ateities sandoris yra sutartis, kurioje turtas yra valiuta, palūkanų normos, žaliavos, trumpalaikiai ir ilgalaikiai iždo ịsipareigojimai, indèliai. Kiekviena ateities sandorio sutartis turi specifikaciją. Mokslinèje literatūroje daugelis autorių Abdullah (2018) ir Mishin (2018) išskiria pagrindines sutarties sąlygas: sutarties tipas (atsiskaitymas ir pristatymas); sutarties verte (dydis) yra pagrindinio turto suma; terminas - laikotarpis per kurị 
galima perparduoti arba ịsigyti sutartị; pristatymo arba atsiskaitymo data - diena, kai sutarties šalys turi ivykdyti savo įsipareigojimus; minimalus kainų pokytis (žingsnis); minimalaus kainų pokyčio sąnaudos.

Akcijų rinkose galimi du kainų santykio atvejai: kontango ir bekvordacija (žr. 1 paveikslą).

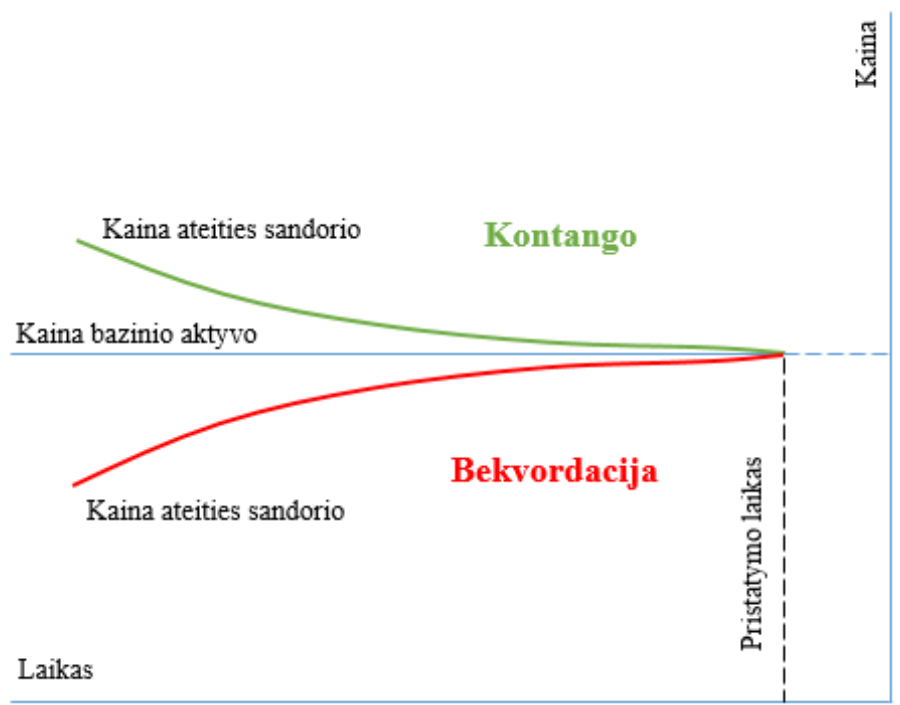

1 paveikslas. Kontango ir bekvordacija biržinèje rinkoje (sudaryta autorès, remiantis Abdullach, 2018)

Kontango (angl. Contango) - tai tokia padetis rinkoje, kurioje mainų sutarčių vertė yra daug pigesnè, nes terminas yra artimiausioje ateityje arba šiuo metu. Kontango yra tada, kai ateities sandorių kaina yra didesnè už numatomą ateities kainą. Kadangi ateities sandorių kaina turi sutapti su tikètina būsimaja neatidèliotinu sandoriu kaina, reiškia, kad ateities sandorių kainos laikui bėgant krinta, nes nauja informacija suderina jas su tikètinomis ateities rinkos kainomis (Tatyannikov, 2017). Bekvordacija (angl. Backwardation) - tai situacija, kai ateities sandorių kaina yra mažesnè už numatomą būsimą neatidèliotiną kainą. Tai pageidautina spekuliantams, kurie ilgisi savo pozicijų: nori, kad ateities sandorių kaina pakiltų. taigi bekvordacija yra tada, kai kyla ateities sandorių kainos.

Dogovora (2017) išskiria ateities sandorio ypatybes:

- terminuotas laikas. Kiekvienas ateities sandoris turi griežtai nustatytą galiojimo terminą, jo neįmanoma nusipirkti neribotam laikui, kaip pavyzdžiui akcijų ar obligacijų;

- forma. Daugelis ateities sandorių yra fizinio turto išraiška, kaip įsipareigojimas pirkti arba parduoti, kažkokị turtą;

- sandorio sudarymas ateityje. Tai yra dokumentais ịtvirtintas pažadų realizavimas, o prekybos objektas kol kas netgi gali ir neegzistuoti. Atsižvelgiant ị tai, kad sandoris yra gana trapus biržos ir valstybès griežtai kontroliuoja būsimų sandorių sutartis, o tai neleidžia sukčiauti.

Ateities sandorių rinka yra gana ịvairi ir išsivysčiusi. Šiandien ji yra viena didžiausių finansų rinkų, nuolat auganti ir apimanti visas naujas priemones ir technologijas. Paprastai ateities sandoris galioja tris menesius, kai prekiautojas gali laisvai prekiauti ir pirkti, kad padidintų savo pelną. Perkant ateities sandorius, nereikia mokèti visos kainos, tik užstato dydị (paprastai 10 proc. kainos) (Gautami, 2018). Taigi galima aktyviai prekiauti biržoje net ir su nedideliu indèliu. Pelnas gaunamas ne dèl turto kainos skirtumų pardavimo ir pirkimo momentu, bet dèl maržos svyravimu. Maržos varijavimas yra dienos sandoriu kainos svyravimas. Priklausomai nuo to, kiekvieną dieną nuo savininko sąskaitos nurašomas skirtumas arba gaunamas pelnas. Ateities sandorių rinkoje yra galimybė atlikti vienu metu didelį operacijų skaičių. Ateities sandoriai yra griežtai reglamentuoti, suteikia garantijas, kad bus ìvykdytos sutartyje numatytos prievolès, todèl yra laikomos viena patikimiausių finansinių priemonių. Galima teigti, kad ateities sandorių rinka yra gana patraukli, nes galima uždirbti pinigus net su mažu kapitalu dèl didelio sverto ir nereikia mokèti visos turto vertės. Tačiau, kita vertus, kasdienis maržos nurašymas, kai strategija yra netinkama ar neraštinga, gali sukelti nulines sąskaitas ir lěšų praradimą. Todèl toliau tikslinga aptarti ateities sandoriu privalumus ir trūkumus.

Em ir Bulychev (2016) išskiria ateities sandorių privalumus ir trūkumus (žr. 1 lentelę).

Taigi, ateities sandoriai yra būsimo turto ịsigijimo sutartys pagal konkretų kainų susitarimą biržoje. Šis ịrankis yra populiarus mainų prekybos objektas, labai likvidus ir patikimas. Tačiau ateities sandorių skubumas neleidžia investuoti - tokia rinka tinka tik aktyviai spekuliacijai.

Ateities sandoris yra nulinės sumos lošimas, kai vieno dalyvio laimėjimas yra lygus kito dalyvio pralaimëjimui. Pagrindinis prekybos ateities sandoriais tikslas - apsisaugoti nuo pasaulio žaliavų ar vertybiniu popieriu kainų svyravimų ir nepageidaujamos kaitos (Sidorenko, 2018). 
1 lentelè. Ateities sandorių privalumai ir trūkumai (sudaryta autorès, remiantis Em ir Bulychev, 2016)

\begin{tabular}{|l|l|}
\hline \multicolumn{1}{|c|}{ Privalumai } & \multicolumn{1}{c|}{ Trūkumai } \\
\hline $\begin{array}{l}\text { Sandoris sudaromas pagal supaprastintą schemą ir } \\
\text { iš karto, o tai reiškia, kad neprarandami pinigai } \\
\text { keičiant kotiruotes užsakymo vykdymo metu. }\end{array}$ & $\begin{array}{l}\text { Netinka investicijoms ir ilgalaikiams sandoriams, nes kiekvienos } \\
\text { sutarties galiojimo laikas yra ribotas iki kelių mėnesių. }\end{array}$ \\
\hline Galima dalyvauti prekyboje, jei ir nėra kitų aktyvų. & $\begin{array}{l}\text { Sandoris yra svarbus aktyviems spekuliantams, kurie atlieka daug } \\
\text { trumpalaikių sandorių, siekdami padidinti pelną. }\end{array}$ \\
\hline Nereikia didelio kapitalo, nes užtenka tik užstato. & Prekyba dideliu svertu siejama su didele rizika. \\
\hline $\begin{array}{l}\text { Didelis sverto mastas, praplečia prekybininko } \\
\text { galimybes. }\end{array}$ & $\begin{array}{l}\text { Dėl maržos svyravimų, kiekvieną dieną nuo savininko sąskaitos } \\
\text { nurašomas skirtumas arba gaunamas pelnas. }\end{array}$ \\
\hline $\begin{array}{l}\text { Dėl didelio turto likvidumo, ji galimą realizuoti } \\
\text { beveik akimirksniu, nelaukiant pirkejo. }\end{array}$ & \\
\hline Garantuotas įsipareigojimų pagal sutartị vykdymas. & \\
\hline
\end{tabular}

Pasaulyje išvestinės finansinès priemonės atlieka svarbų vaidmeni priimant finansinius sprendimus. Ateities sandorių augimo dinamika pasaulyje per pastaruosius metus rodo (žr. 1 paveikslą), kad jautriausia finansų rinkos dalis sparčiai vystosi. Maži transakcijų kaštai bei lengvas šių priemonių panaudojimas suteikia įmonèms daug galimybių kryptingai planuoti pinigų srautus bei visą dèmesį sutelkti ị pagrindinę veiklą.

Pasaulio finansų rinkoje lyderiai yra Azijos šalys, Šiaurès Amerika ir Europa, kuriose labiausiai išvystytos finansų rinkos. Viena priežasčių, kodèl ateities sandorių rinka auga, yra ta, kad ji jautriai reaguoja į rinkos pokyčius ir greitai nustato teisingą kainą. Ateities sandoriai leidžia įmonei pakeisti rizikos profilį.

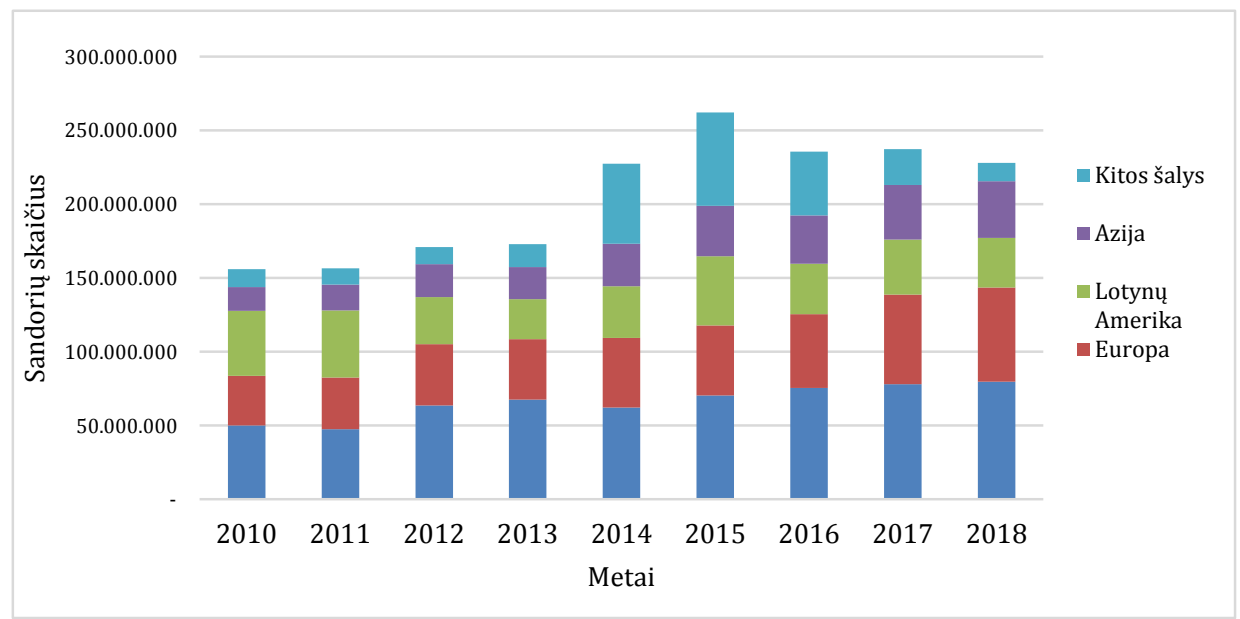

2 paveikslas. Ateities sandorių augimo dinamika pasaulyje 2010-2018 m. (sudaryta autorès, remiantis Fia, 2018)

Pagal 2 paveikslą galima įžvelgti, kad pasaulinėje biržoje išvestinių finansinių priemonių rinka nuo $2010 \mathrm{~m}$. iki 2018 m. pakilo ị rekordines aukštumas. Po pasaulinès finansinès krizès $2010 \mathrm{~m}$. išvestinių finansinių priemonių rinka sparčiai ịsiveržė i pasaulio rinką. $2012 \mathrm{~m}$. ateities sandoriai patyrè nuostolị visuose regionuose ir $2013 \mathrm{~m}$. atsigavo bei nusistovejjo, o $2015 \mathrm{~m}$. rodè teigiamą tendenciją. Dèl ateities ir pasirinkimo sandorių pasikeitè mainai visame pasaulyje, kurie padidejo 20,2 proc. iki 30,28 mlrd. sandorių $2018 \mathrm{~m}$., o ateities sandorių apimtys padidejjo 15,6 proc. t. y. 17,15 mlrd. sutarčių. Augimo tempas buvo sparčiausias nuo 2010 m. Jị paveikè Azijos ir Ramiojo vandenyno bei Lotynų Amerikos regionai, kur valiutos keitimo apimtys padidejjo 27,1 proc., o Šiaurès Amerikos palūkanų normos sektorius atsigavo 26,4 proc.

Apžvelgus statistinius duomenis 2010-2018 m. pagal sandorio rūšį, (žr. 3 paveikslą) galima įžvelgti, kad prekyba akcijų indeksų ateities sandoriais ir pasirinkimo sandoriais, buvo vienas iš pagrindinių veiksnių, skatinančių bendrą prekybos augimą $2018 \mathrm{~m}$. Pasaulio akcijų indekso apimtys padidejo iki 32,8 proc. t. y. 9,98 mlrd. sutarčių lyginant su 2017 m. Dèl padidejusios prekybos Indijoje, Brazilijoje ir Argentinoje 31,7 proc. arba 3,93 mlrd. sutarčių padidèjo valiutų ateities sandorių. Palūkanų normos prekyba, sutelkta ị Šiaurès Amerikos ir Europos biržas, padidejjo 14,8 proc. Tai treti metai iš eilès, kai palūkanų normos prekybos rezultatai rodo teigiamą tendenciją. Per paskutiniuosius metus sumažejo nebrangiujų metalų sutarčių kiekis 12,5 proc., tačiau išaugo energetikos, brangiujų metalų, žemès ūkio produktų ateities sandoriai.

Galima teigti, kad išvestinių finansinių priemonių prekyba biržose visame pasaulyje sparčiai didejja, vadinasi šie finansiniai instrumentai yra paklausūs vartotojams ir investuotojams. Prekybos ateities sandorių augimą lemia padidejusi pasaulinė paklausa ir vis aktyvesnis el. prekybos sistemų naudojimas. 


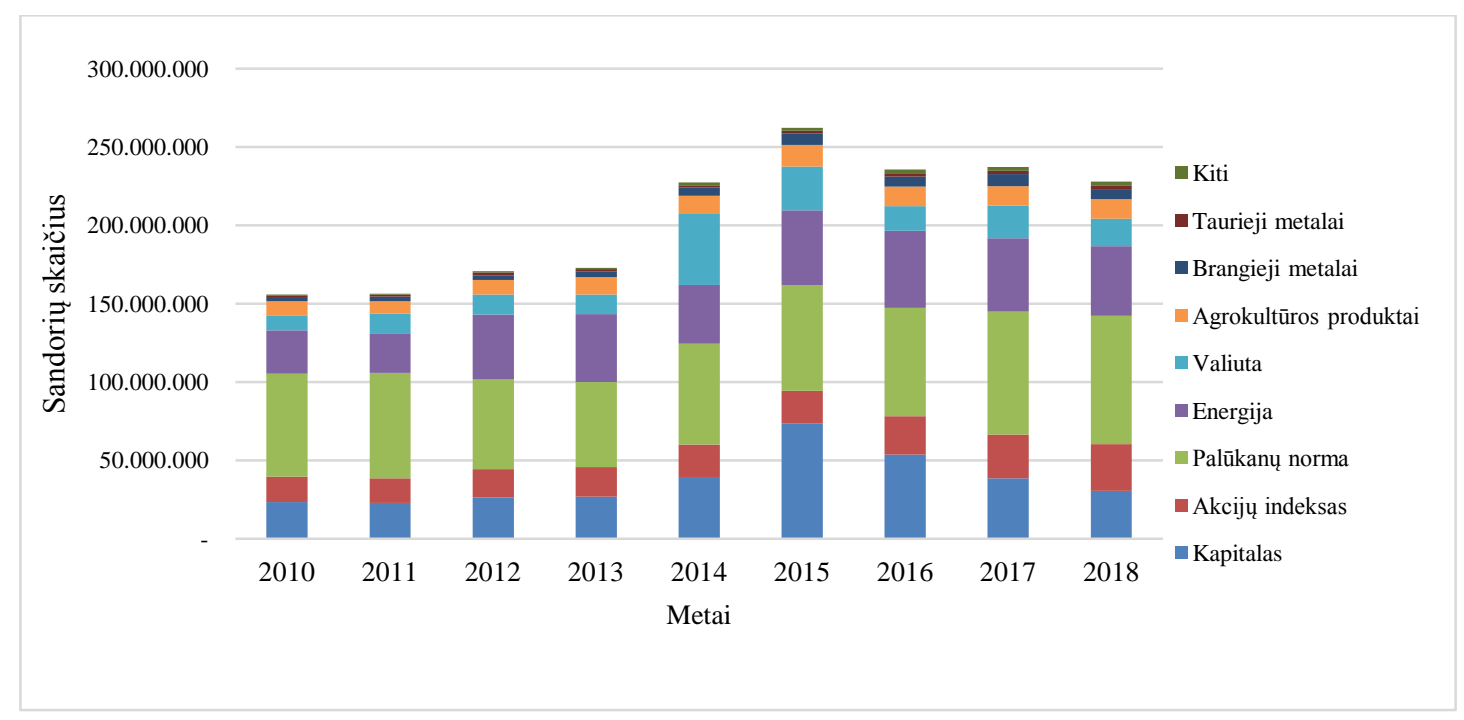

3 paveikslas. Ateities sandorių augimo dinamika pasaulyje 2010-2018 m. pagal sandorio rūšị (sudaryta autorès, remiantis Fia, 2018)

Neautomatinė prekyba vertybinių popierių biržoje, nepaisant jos pranašumų ir pelningumo, užtikrintai yra praeitis. Šiuo metodu prekiauja tik senosios mokyklos prekybininkai, o pradedantieji pirmenybę teikia automatinėms operacijoms (Martín et al., 2019). Tobulëjant kompiuterinėms technologijoms ir atsiradus prekybai internetu, pasaulyje finansų rinkos pradėjo plètoti naują sandorių kryptị, paremtą naudojant specialias programas prekybos robotus. Juose ịterpti algoritminiai sandoriai leidžia, remiantis rinkos duomenų analize, automatiškai sudaryti rinkos sandorius, tiesiogiai nedalyvaujant prekybininkui (Shchennikov, 2018) Prekybos automatizavimas suteikia galimybę efektyviai išnaudoti kainų dinamikos tendencijas.

Kardinaliai pasikeitė elektroninės prekybos tarptautinėse finansų rinkose būdai, nes vis daugiau prekybos proceso etapų radikaliai pakeisti elektroninėmis priemonėmis. Vienas iš naujausių pokyčių yra algoritminè prekyba, kuri pirmiausia nukreipta ị numanomų transakcinių išlaidų sumažinimą vykdant pavedimus. XX amžiaus pabaigoje sparčiai vystantis kompiuterinems technologijoms, keitesi prekybos procesas finansų rinkose, kurios beveik visiškai tapo elektroninemis. Algoritmine prekyba tokia forma, kokia ji yra žinoma šiandien, atsirado praejusio amžiaus aštuoniasdešimtaisiais metais. Tais laikais paprastiems prekybininkams tokia prekyba buvo nęmanoma, ja naudojosi tik instituciniai investuotojai, kurie galèjo sau leisti didelę skaičiavimo galią ir turèjo i̇spūdingu intelektinių išteklių (Ruiz-Cruz, 2018). Šiandien automatine prekyba gali naudotis bet kuris paprasto asmeninio kompiuterio savininkas.

Apibendrinant galima teigti, kad daugelis mokslininkų, apibūdinančiu algoritminę prekybą, laikosi panašios nuomonès, kad tai automatizuota kompiuterine sistema, pagrista matematiniais algoritmais. Šiuo metu akademinè ir bendroji literatūra apie algoritminę prekybą yra gana plati. Algoritminès prekybos apibrěžimai svyruoja nuo labai bendro apibrēžimo kaip kompiuterinės prekybos, valdomos algoritmų, iki gana specifinės - kaip algoritminėje prekyboje kompiuteriai tiesiogiai sąveikauja su prekybos platformomis ir pateikia pavedimus be tiesioginio žmogaus ịsikišimo. Kompiuteriai labai dažnai stebi rinkos duomenis ir galbūt kitą informaciją ir, remdamiesi i̇montuotu algoritmu, siunčia prekybos instrukcijas, dažnai per milisekundę, naudodami daugybę algoritmų (Moriyasu et al., 2018).

\section{Ateities sandorių tyrimo metodologija}

Formuojant investicinị portfelị yra daug teorijų ir metodụ. Išanalizavus mokslinę literatūrą, tyrimui atlikti pasirinkti du vienas kitą papildantys metodai - Monte Carlo ir Sharpo metodai, kuriais siekiama bus įvertinti kainų kitimo tendencijas ir gautų prognozių pagrindu sudaryti investicini portfeli.

Monte Carlo metodas. Monte Carlo metodu gaunamos statistinès išvados, imitavimo metodais kartojant eksperimentus kompiuteriuose. Šis metodas gali supaprastinti kai kuriuos sudètingus matematinius modelius ir generuoti duomenis, kurie gali būti tolesnès analizės pagrindas (Kogdenko, 2018). Jis plačiai naudojamas gamtos moksluose, statistikoje ir finansuose. Finansininkas gali imituoti finansinio turto grąžos laiko eilutes ir atlikti tolesnius šių duomenų tyrimus.

Klasikinio Monte Carlo prognozės metodo formulę Ermakov ir Sipin (2014) apibrežia taip (žr. (1) ir (2)):

$$
S(t+\Delta t)=S(t) e^{\left(\delta+\frac{1}{2} \sigma^{2}\right) \Delta t+\sigma \sqrt{\Delta t Z}},
$$


čia: $S(t)$ - vertė laiko momentu, $t ; Z$ - atsitiktinès reikšmès iš standartinio normaliojo skirstinio; $\Delta t-$ prognozavimas; $\sigma$-logoritmuotų finansinių priemonių standartinis nuokrypis; $\delta$-grąžos vidurkis.

Grąžos vidurkis apskaičiuojamas:

$$
\delta=\frac{1}{n} \sum_{i=1}^{n} \log \left(\frac{S_{i}}{S_{i-1}}\right),
$$

čia: $n$ - finansinių priemonių kiekis.

Šio modelio privalumas tas, kad jis lengvai naudojamas, tačiau jis laikomas statistiškai pagrịstu tuomet, kai algoritmuotas finansinių priemonių grąžos normos yra priskaičiuotos pagal normalujji dèsnị.

Sharpo metodas. Sharpo metodas yra būdas įvertinti investicijos rezultatus, koreguojant pagal jos riziką. Vykdydamas investicinę veiklą, investuotojas nori iškęsti didesnę svyravimo riziką, kai tikimasi didesnès grąžos, taigi, pagrindinè Sharpo metodo ideja yra tokia: racionaliam investuotojui pagrindinis pasirinkto investicinio portfelio laimèjimas yra tas, kuris siekia maksimalios tikètinos grąžos su fiksuota rizika arba siekti mažiausios rizikos pagal fiksuotą numatomą grąžą (Masry, 2017). Masry (2017) apibrèžia (žr. (3)) Sharpo rodiklio formulę:

$$
S=\frac{R-R_{f}}{\sqrt{\operatorname{VAR}\left[R-R_{f}\right]}},
$$

čia: $R$ - portfelio grąža; $R_{f}$ - nerizikinga norma; $V A R[.$.$] - dispersija.$

Šis rodiklis yra vienas iš labiausiai paplitusių tarp investuotojų, jis leidžia palyginti skirtingus portfelius remiantis klasikiniu rizikos supratimu.

Apibendrinant galima teigti, kad sujungiami du algoritmai - prognozuojantis atskirus instrumentus Monte Carlo metodas ir optimizuojantis, leidžiantis sudaryti efektyvų portfeli Sharpo metodas, kurie kartu jau tampa paramos sistema investuotojui. Monte Carlo metodas prognozuos kainų kitimo kryptis, tendencijas ir įejjimo į rinką laiką, o Sharpo metodas numatys ryši tarp kiekvieno finansinio instrumento pelningumo ir rizikos. Taigi, sudarant investicini portfeli reikia labai atsargiai pasirinkti portfelio sudarymo metodą bei atsižvelgti ị makroekonominių veiksnių poveikį, kad nebūtų prarastas turimas kapitalas. Pasitelkus šiais dvejais metodais galima siekti sẻkmingo investicinio portfelio.

\section{Ateities sandorių kainų prognozès tyrimo rezultatai}

Apžvelgus ateities sandorio rinkos analizę, pasirinktos trys finansinès priemonès - naftos, aukso ir gamtinių dujų. Naudojant MATLAB programą ir pasitelkiant algoritminiais metodais - Monte Carlo ir Sharpo - pateikiami šių finansinių priemonių $2015 \mathrm{~m}$. - $2019 \mathrm{~m}$. gauti kainų kitimo tendencijų grafikai, siekiant numatyti galimas kainų kitimo kryptis ir tendencijas bei sudarytas ateities sandorio investicinis portfelis.

Pirma buvo atliktas Monte Carlo metodas pasitelkiant MATLAB programa (Matlab algoritmas, 2019b) apžvelgiant finansinių priemonių kainos kitimą ir tendenciją. Žemiau (žr. 4, 5 ir 6 paveikslus) pavaizduota naftos, aukso ir gamtinių dujų ateities sandorių kainos kitimo grafikai nuo 2015 m. sausio mėn. iki 2019 m. lapkričio mèn.

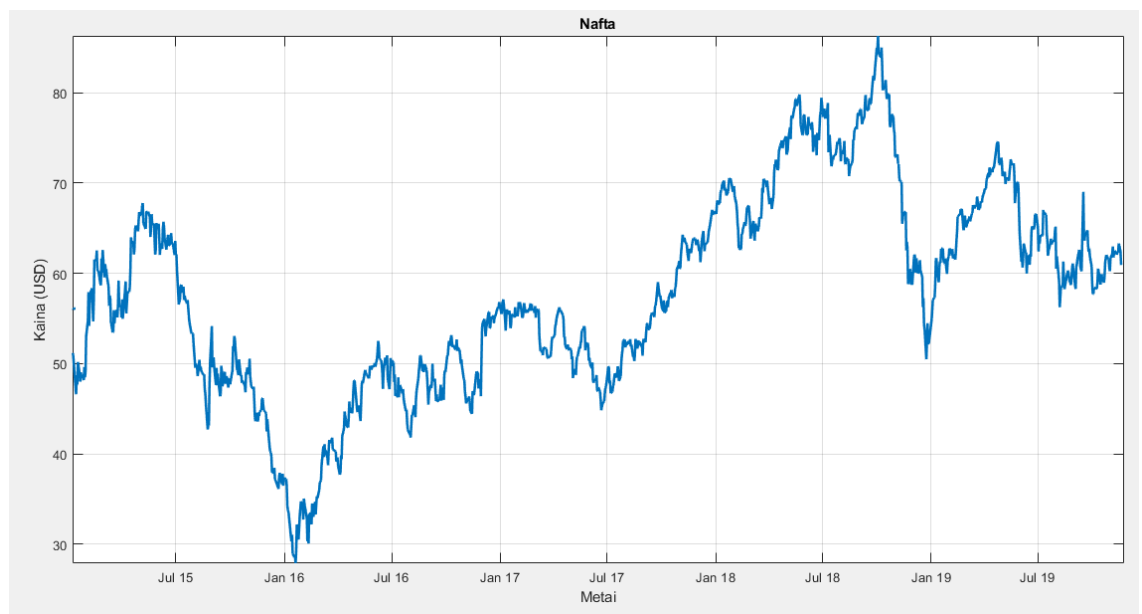

4 paveikslas. Naftos ateities sandorio kainų kitimo tendencijos 2015-2019 m (sudaryta autorès, remiantis „Investing.com“, 2019 duomenimis ir MATLAB programa, 2019) 
Analizuojant naftos ateities sandorio kainų kitimo grafiką $2015 \mathrm{~m}$. sausio - $2019 \mathrm{~m}$. lapkričio mèn. galima matyti, kad per nagrinèjamą laikotarpi 2016 m. liepos mėn. kaina buvo pasiekusi žemiausią tašką, siekẻ 27 USD. Nuo 2016 m. iki 2017 m. liepos mènesio kainos vertè svyravo. 2017 m. liepos mèn. kaina tai krito, tai kilo ir vèl krito, tačiau iki 2018 m. rugpjūčio mèn. kaina vis tiek pakilo ir aukščiausia kaina ir buvo apie 90 USD. Tačiau, taip pat, $2018 \mathrm{~m}$. rugpjūčio mènesị, kaina staigiai krenta ir siekia 50 USD. Pateiktame grafike (žr. 4 paveikslą) prognozuojamas laikotarpis pažymėtas pilku fonu. Iš grafiko galima matyti, kad nuo $2019 \mathrm{~m}$. sausio mènesio kaina didèja, tačiau ir nežymiai svyruoja, tiek pakildama, tiek nukrisdama. Žvelgiant i prognozuojamą kainos ribą, galima matyti, kad kaina nežymiai svyruoja, todẻl galima daryti išvadą, kad kaina turètų kristi ir tai būtų puiki galimybė investuoti ị naftos ateities sandorị ir tikètis nemažos grąžos.

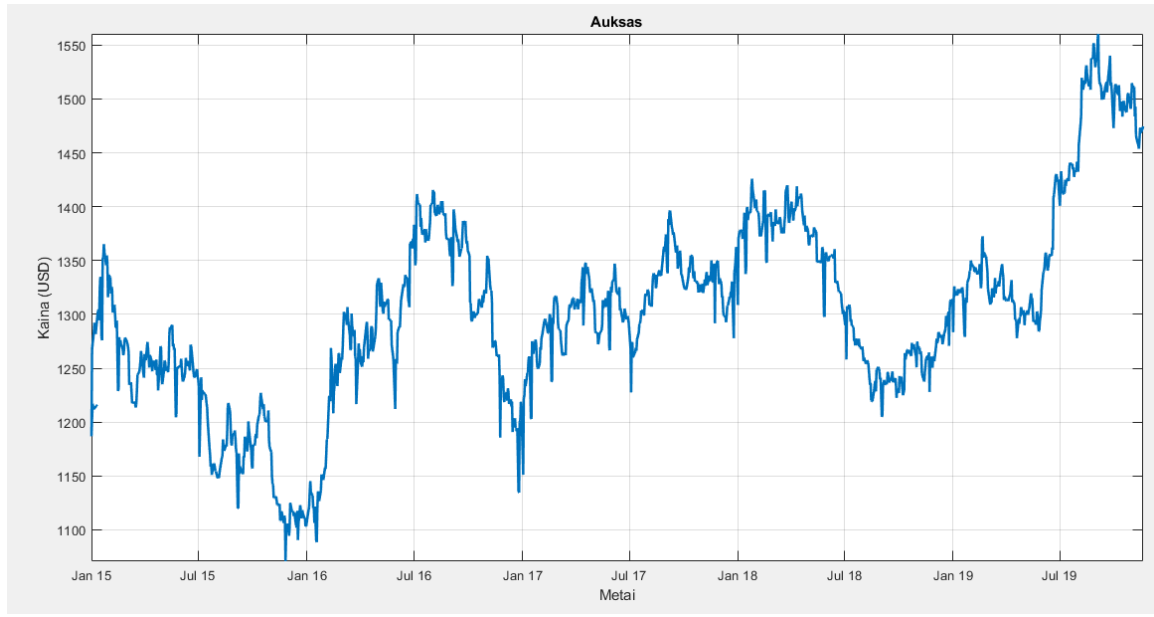

5 paveikslas. Aukso ateities sandorio kainų kitimo tendencijos 2015-2019 m

(sudaryta autorès, remiantis „Investing.com“, 2019 duomenimis ir MATLAB programa, 2019)

Nagrinejjant prekybos auksu ateities sandorių kainų kitimo grafiką 2015-2019 m. galima jžzvelgti kainų svyravimus su bendra kainų didejjimo tendencija. Nuo $2015 \mathrm{~m}$. sausio mènesio iki $2016 \mathrm{~m}$. aukso produkto kaina krenta ir pasiekia žemiausią tašką per visą nagrinejjamą laikotarpi - 1000 USD. Nuo $2016 \mathrm{~m}$. sausio mènesio kaina iš žemiausio taško didejja ir pasiekia 1450 USD kainą, tačiau ižzvelgiami ir kainos svyravimai. Nuo $2016 \mathrm{~m}$. liepos mèn. aukso ateities sandorio kaina vèl krenta ir siekia 1155 USD. 2017 m. pradžioje kaina palaipsniui, ryškiai svyruodama kyla iki 1400 USD kainos, tačiau pasiekusi ši tašką kaina vèl krenta iki 1200 USD. Nuo 2018 m. vidurio kaina svyruoja ir 2019 m. viduryje pasiekia aukščiausią tašką - 1550 USD per visą nagrinejjamą laikotarpị. Žvelgiant ị pilkają prognozuojamą kainos ribą (žr. 5 paveikslą) galima matyti ir daryti išvadą, kad kaina, pasiekusi aukščiausią tašką, turètų kristi.

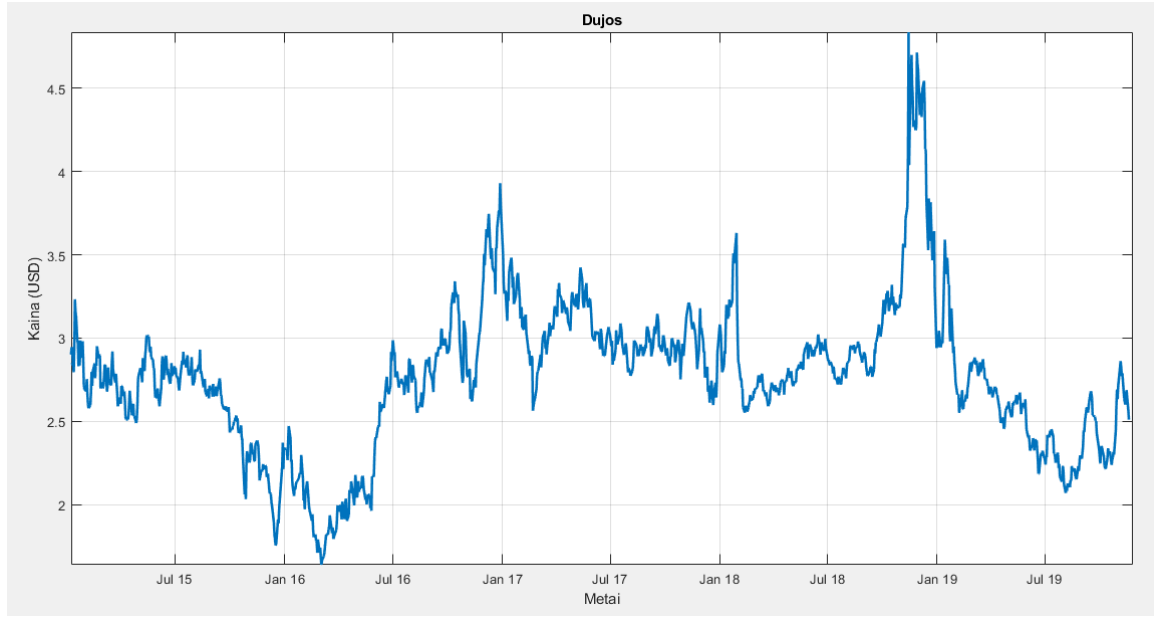

6 paveikslas. Gamtinių dujų ateities sandorio kainų kitimo tendencijos 2015-2019 m. (sudaryta autorès, remiantis „Investing.com“, 2019 duomenimis ir MATLAB programa, 2019)

Žvelgiant ị 6 paveikslą, galima matyti du ryškius kainų pakilimus: vieną - per 2016 m., antrą - 2018 m. Per 2017 m. matomi nežymūs rinkos kainų svyravimai, kur kainos tai pakildavo, tai nukrisdavo. Žemiausia kaina per 
nagrinejjamą laikotarpi buvo $2016 \mathrm{~m}$. pradžioje, o aukščiausiai pakilusi kaina - $2018 \mathrm{~m}$. pabaigoje, po kurios ženkliai pradejjo kristi. Matoma, kad 2019 m. kaina svyruoja ir šiek tiek kyla. Iš prognozuojamos kainos ribos, kuri pažymèta pilku fonu (žr. 6 paveikslą) galima matyti, kad kaina turi kilimo tendenciją su gana ryškiais pakilimais ir nukritimais, todèl grafike galima įžvelgti, kad kaina kyla.

Atlikus kainų prognozavimą Monte Carlo metodu galima matyti vaizdą, apie tai, kas vyksta prekių rinkoje. Visų pasirinktų finansinių priemonių kainų dinamika per 2015-2019 metus rodo bendras kritimo tendencijas, o tai leidžia daryti prielaidą, kad kainos ateityje pradès kilti ir galima tikètis naudingų ateities sandorių. Norint sẻkmingai prekiauti biržoje ateities sandoriais, svarbu pasirinkti tinkamą laiką patekti į rinką ir laiku išeiti iš jos.

Atlikus finansinių priemonių kainų kitimo tendencijas Monte Carlo metodu, gautų prognozių pagrindu sudarytas investicinis portfelis siekiant gauti kuo didesni pelną su mažiausia rizika naudojant Sharpo metodą MATLAB programa (Matlab algoritmas, 2019a). Pagrindinis investicinio portfelio formavimo tikslas - išlaikyti ir didinti kapitalą. Tuo pat metu, formuojant investicini portfeli siekiama didinti kapitalo ir pajamų augimą bei užtikrinti saugumą ir likvidumą. Norint išvengti rizikos ir turèti didesnị pelną, sudarant investicinị portfelị, buvo pasitelktas diversifikacijos principas. Išnagrinėjus ateities sandorių rinkos vystymąsi ir tendencijas buvo sudaromas investicinis portfelis tauriujų metalų, žaliavų ir metalų sektoriuose. Žemiau (žr. 7 paveikslą) pavaizduotas gautų rezultatų grafikas, čia ant efektyviosios linijos raudonai pažymètas portfelis su maksimaliu Sharpe rodikliu.

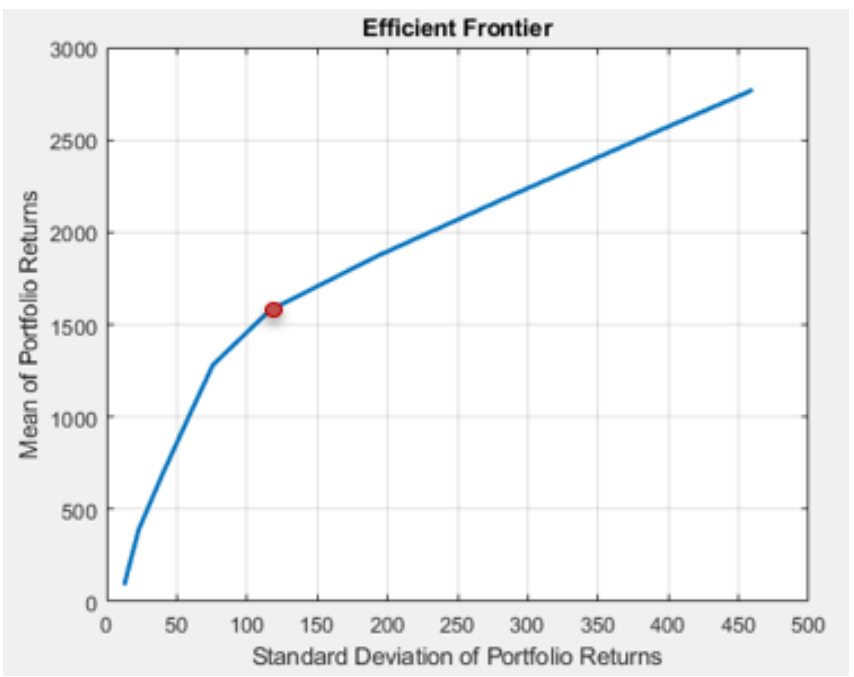

7 paveikslas. Sharpo metodo tyrimo rezultatai (sudaryta autorès, MATLAB programa, 2019)

Tai yra unikalus rizikos, grąžos taškas, maksimaliai padidinantis Sharpo rodiklio santykị. Kaip teigia Wang et al. (2019) neįmanoma pasiekti aušto grąžos lygio be rizikos. Padidèjus dideliam pelnui, didejja ir rizika, taip pat investicija turi būti sudaroma ir numatoma atsižvelgiant ị tam tikrus lygius. Atlikus tyrimą naudojant Shrape metodą buvo sudarytas investicinis portfelis iš trijų ateities sandorio finansinių priemonių - naftos, aukso, gamtinių dujų. Gauti tyrimo rezultatai pateikti 2 lentelèje:

2 lentelè. Gauti tyrimo rezultatai (sudaryta autorès)

\begin{tabular}{|c|c|c|c|}
\hline Priemonės & Nerizikinga grąža & Grąžos vidurkis & Lèšu paskirstymas \\
\hline Nafta & 1,63 proc. & 0,5974 & 59,74 proc. \\
\hline Auksas & 1,63 proc. & 0,3882 & 38,82 proc. \\
\hline Gamtinės dujos & 1,63 proc. & 0,0144 & 1,44 proc. \\
\hline
\end{tabular}

Gauti rezultatai rodo, kad visų finansinių priemonių Sharpo rodiklis yra žemesnis nei rinkos nerizikingos grąžos norma. Tai reiškia, kad tai lemia mažą riziką atitinkančią grąžą. Kadangi Sharpo koeficientas parodo, kiek pelno prieaugio tenka kiekvienam rizikos vienetui, tai iš gautų rezultatų (žr. 2 lentelę) galima matyti, kad formuojant investicinị portfelị didžiausią dalị portfelio investicijos sudarys naftos ateities sandoriai, kurių investicijos turi atnešti 59,74 proc. pelno prieaugio, taip pat nemažą dalị portfelio sudarys investicijos ị auksą, kurio laukiama grąža - 38,82 proc. Mažiausią investicinio portfelio investicinę dalị sudarys gamtinès dujos, kurios turètų atnešti pelno prieaugio tik 1,44 proc. Galima daryti išvadą, kad naftos ir aukso ateities sandoriai turètų būti pelningesni, tačiau su didesne rizika, o gamtinių dujų ateities sandoris mažiau pelningas, tačiau su mažesne tikètina rizika, taip pat proporcingai ir léšos paskirstomos ị portfelị. 


\section{Išvados}

Mokslinejje literatūroje ateities sandoris suprantamas kaip standartizuotas sandoris pirkti arba parduoti sandorio objektu esantį turtą, issipareigojimus už kainą, kuri galios sandorio vykdymo metu. Pasaulinės ateities rinkos statistiniai duomenys rodo, kad ateities sandoriai turi perspektyvą augti, nes jautriai reaguoja ị rinkos pokyčius, greitai nustato teisingą finansiniu priemonių kainą, net esant finansinèms krizèms. Atlikus ateities sandorių rinkos analize pastebèta, kad ateities sandorių prekyba visame pasaulyje sparčiai didèja ypač Azijos šalyse, Šiaurès Amerikoje ir Europoje. Per paskutiniuosius metus ženkliai padidèjo valiutos, brangiujų metalų ir energetikos ateities sandoriai. Prekybai ateities sandoriais pasirinktos tokios finansinès priemonès: nafta, auksas ir gamtinès dujos. Darbe buvo sujungti du algoritmai: prognozuojantis Monte Carlo metodas, kuris rodo atskirų instrumentu kitimo tendencijas, leidžia ižzvelgti pirkimo ir pardavimo signalus, rinkos aktyvumą ir pasyvumą bei pasirinkti ¡̇ejimo ị rinką laiką, kad prekyba būtų pelninga; kitas -optimizuojantis, leidžiantis sudaryti efektyvų portfelį, su didžiausiu Sharpo rodikliu. Šie algoritmai kartu tapo paramos sistema investuotojui.

Atlikus kainu prognozavimą Monte Carlo metodu naftos ateities sandorio grafikas rodè kainos kritimo tendenciją, aukso ateities sandorio grafikas rodè taip pat kainos kritimo tendenciją, o gamtinių dujų ateities sandorio kainų grafikas prognozavo kainos kilimo tendenciją.

Atlikus tyrimą naudojant Sharpo metodą buvo sudarytas investicinis portfelis iš triju ateities sandorio finansinių priemonių - naftos - tenkanti 59,74 proc. lěšu paskirstymo dalis, aukso - tenkanti 38,82 proc. lëšų paskirstymo dalis ir gamtinių dujų - 1,44 proc. dalis. Gauti rezultatai rodo kad visų finansinių priemoniu Sharpo rodiklis yra žemesnis nei rinkos nerizikingos grąžos norma $(1,62)$. Tai reiškia, kad tai lemia mažą riziką atitinkančią grąžą. Naftos ateities sandorio grąžos vidurkis - 0,5974 ; aukso ateities sandorio grąžos vidurkis - 0,3882 ; gamtiniu dujų ateities sandorio grąžos vidurkis - 0,0144. Sharpo koeficientas parodo, kiek pelno prieaugio tenka kiekvienam rizikos vienetui, tai iš gautų rezultatų galima matyti, kad formuojant investicinị portfelị didžiausią dalị portfelio investiciju sudarys naftos ateities sandoriai, kurių investicijos turi atnešti 59,74 proc. pelno prieaugio, taip pat nemažą dalị portfelio sudarys investicijos i auksą, kurio laukiama grąža $-38,82$ proc. Mažiausią investicinio portfelio investicinę dalị sudarys gamtinės dujos, kurios turètų atnešti pelno prieaugio tik 1,44 proc. Galima daryti išvadą, kad naftos ir aukso ateities sandoriai turètų būti pelningesni, tačiau su didesne rizika, o gamtinių dujų ateities sandoris mažiau pelningas, tačiau su mažesne tikètina rizika. Taigi apibendrinant galima teigti, kad pritaikant Monte Carlo prognozavimo metodą ir pasitelkus gautais prognozės rezultatais sudarytas investicinis portfelis Sharpo metodu rodo, kad investicija ị šias ateities sandorio priemones - auksą, naftą ir gamtines dujas turètų būti perspektyvi, atnešanti tikètiną laukiamą grąžą su nedidele rizika.

\section{Literatūra}

Abdullah, A. A. (2018). Derivativy kak instrument upravleniya finansovymi riskami. Ekonomika i sovremennyy Menedzhment, 9(3), 149-155. https://elibrary.ru/item.asp?id=34924961

Dogovora, F. (2017). Ponyatie i kharakternye osobennosti f'yuchersnogo dogovora. Vestnik Instituta Zakonodatel'stva RK, 3(48), 165-171. https://cyberleninka.ru/article/n/ponyatie-i-harakternye-osobennosti-fyuchersnogo-dogovora

Em, S. E., \& Bulychev, S. I. (2016). Istoriya vozniknoveniya forvardnykh i f'yuchersnykh kontraktov. Upravlenie. Biznes. Vlast', 1(10), 111-114. https://elibrary.ru/item.asp?id=25801777

Ermakov, S. M., \& Sipin, A. S. (2014). Metod Monte-Karlo i parametricheskaya razdelimost' algoritmov. St. Petersburg.

FIA. (2018). Annual trading statistics showing record ETD volume in 2018. https://fia.org/articles/fia-releases-annualtrading-statistics-showing-record-etd-volume-2018

Gautami, S. (2018). A study on financial derivatives with reference to Tata Motors Limited, Chittoor district of AP, India. GJRA - Global Journal for Research Analysis, 7(4), 20-23. https://www.researchgate.net/

Karali, B., McNew, K., \& Thurman, W. N. (2018). Price discovery and the basis effects of failures to converge in soft red winter wheat futures markets. Journal of Agricultural and Resource Economics, 43(1), 1-17.

Kogdenko, V. (2018). Strategicheskoe modelirovanie pribyli kompanii metodom Monte-Karlo. Economic Analysis: Theory and Practice, 17(9), 1622-1641. https://doi.org/10.24891/ea.17.9.1622

Lutsenko, E., Loyko, V., \& Baranovskaya, T. (2017). Ot upravleniya investitsiyami k upravleniyu s pomoshch'yu investitsiy. Ekonomika i Biznes, 24(4), 1-10. https://cyberleninka.ru/article/n/ot-upravleniya-investitsiyami-k-upravleniyu-spomoschyu-investitsiy

Martín, C., Quintana, D., \& Isasi, P. (2019). Grammatical Evolution-based ensembles for algorithmic trading. Applied Soft Computing Journal, 84, 105713. https://doi.org/10.1016/j.asoc.2019.105713

Masry, M. (2017). The impact of technical analysis on stock returns in an Emerging Capital Markets (ECM's) country: Theoretical and empirical study. International Journal of Economics and Finance, 9(3), 91. https://doi.org/10.5539/ijef.v9n3p91

Matlab algoritmas. (2019a). Efektyvusis portfelis maksimizuojant Sharpe rodikli. https://ch.mathworks.com/help/finance/efficient-portfolio-that-maximizes-sharpe-ratio.html

Matlab algoritmas. (2019b). Monte Carlo prognozavimo modelis. https://ch.mathworks.com/help/econ/vec-model-montecarlo-forecasts.html 
Mishin, A. (2018). Treyding prostymi kalendarnymi spredami f'yuchersov na zoloto. Finance and Credit, 24(4), 227-237. https://doi.org/10.24891/fc.24.1.227

Moriyasu, H., Wee, M., \& Yu, J. (2018, March). The role of algorithmic trading in stock liquidity and commonality in electronic limit order markets. Pacific Basin Finance Journal, 49, 103-128. https://doi.org/10.1016/j.pacfin.2018.04.004

Ruiz-Cruz, R. (2018). Portfolio modeling for an algorithmic trading based on control theory. IFAC-PapersOnLine, 51(13), 390-395. https://doi.org/10.1016/j.ifacol.2018.07.310

Saakian, D. B. (2018). Statistical mechanics and financial markets: Antagony between derivatives and market self-regulation. Chinese Journal of Physics, 56(3), 988-993. https://doi.org/10.1016/j.cjph.2018.03.017

Shchennikov, A. N. (2018). Situatsionnoe modelirovanie v algoritmicheskom obespechenii. ITNOU: Informatsionnye Tekhnologii v Nauke, Obrazovanii i Upravlenii, 2(16), 94-100.

Sidorenko, Yu. (2018). Mirovye tendentsii razvitiya rynka derivativov. Bankay̆ski Vesnik, 4(657), $37-45$. http://www.nbrb.by/bv/arch/657.pdf

Tatyannikov, V. A. (2017). Futures contracts: modern peculiarities of circulation. Upravlenets, 67(3), $62-67$. https://doi.org/10.29141/2218-5003-2017-5-3-8

Vo, D., Huynh, S., Vo, A., \& Ha, D. (2019). The importance of the financial derivatives markets to economic development in the world's four major economies. Journal of Risk and Financial Management, 12(1), 35. https://doi.org/10.3390/jrfm12010035

Wang, Z., Ho, S. B., \& Lin, Z. (2018, November 17-20). Stock market prediction analysis by incorporating social and news opinion and sentiment. In IEEE International Conference on Data Mining Workshops (pp. 1375-1380). https://doi.org/10.1109/ICDMW.2018.00195

\title{
INVESTING IN FUTURE TRADE USING MONTE CARLO AND SHARP METHODS
}

\author{
Ieva ŽOLNEROVIČIŪTĖ, Nijolè MAKNICKIENĖ
}

\begin{abstract}
The global derivatives market is a dynamically growing segment of the financial market. New financial products complicate economic relations and require new financial innovations. The emergence of a global network economy that relies on its electronic operating systems, shifts billions of dollars to the rest of the world in seconds. Global futures growth dynamics in recent years show that the most sensitive part of the financial market is developing rapidly. The low transaction costs and ease of use of these tools provide investors with plenty of opportunities for purposeful cash flow planning and the desired return. For this reason, it is very important to analyze and properly evaluate the potential price trends and trends of future derivatives. This work combines two algorithms as an investor support system: the Monte Carlo Predictive Approach, which tracks the movement of individual instruments, provides insight into buying and selling signals, market activity and inactivity, and allows for market entry time for profitable trading; the other is the Sharp method of optimizing for an efficient portfolio. Using these algorithms and their results, futures prices are forecasted and an investment portfolio with expected returns and reduced risk is created.
\end{abstract}

Keywords: derivatives, futures, market, algorithmic trading, Monte Carlo method, Sharp method, trends. 